\title{
Evidence of higher photosynthetic plasticity in the early successional Guazuma ulmifolia Lam. compared to the late successional Hymenaea courbaril $\mathrm{L}$. grown in contrasting light environments
}

\author{
Portes, MT. ${ }^{\mathrm{a}, \mathrm{b}}$, Damineli, DSC. ${ }^{\mathrm{a}, \mathrm{b}}$, Ribeiro, $R \mathrm{.}^{\mathrm{c}}$, Monteiro, $J A F^{\mathrm{d}}{ }^{\text {and Souza, }}$ GM. ${ }^{\mathrm{a} *}$ \\ aLaboratório de Ecofisiologia Vegetal, Universidade do Oeste Paulista - Unoeste, \\ Rod. Raposo Tavares, Km 572, CEP 19067-175, Presidente Prudente, SP, Brazil \\ 'Departamento de Botânica, Instituto de Biociências, Universidade Estadual Paulista - UNESP, \\ Av. 24A, 1515, CEP 13506-900, Rio Claro, SP, Brazil \\ 'Setor de Fisiologia Vegetal, Centro de Pesquisa e Desenvolvimento de Ecofisiologia e Biofísica, \\ Instituto Agronômico - IAC, \\ CP 28, CEP 13012-970, Campinas, SP, Brazil \\ ${ }^{\mathrm{d} I n s t i t u t e}$ of Botany, University of Basel, Schönbeinstrasse 6, CH-4056 Basel, Switzerland \\ *email: gustavo@unoeste.br \\ Received September 17, 2008 - Accepted April 7, 2009 - Distributed February 28, 2010
}

(With 3 figures)

\begin{abstract}
The present study investigated changes in photosynthetic characteristics of Guazuma ulmifolia Lam. (early successional species) and Hymenaea courbaril L. (late successional species) grown in contrasting light conditions as a way of assessing photosynthetic plasticity. Early successional species typically inhabit gap environments being exposed to variability in multiple resources, hence it is expected that these species would show higher photosynthetic plasticity than late successional ones. In order to test this hypothesis, light and $\mathrm{CO}_{2}$ response curves and chlorophyll content (Chl) were measured in plants grown in high and low light environments. G. ulmifolia presented the highest amounts of both Chl $a$ and $b$, especially in the low light, and both species presented higher Chl $a$ than $b$ in both light conditions. The Chl $a / b$ ratio was higher in high light leaves of both species and greater in G. ulmifolia. Taken together, these results evidence the acclimation potential of both species, reflecting the capacity to modulate light harvesting complexes according to the light environment. However, G. ulmifolia showed evidence of higher photosynthetic plasticity, as indicated by the greater amplitude of variation on photosynthetic characteristics between environments shown by more significant shade adjusted parameters (SAC) and principal component analysis (PCA). Thus, the results obtained were coherent with the hypothesis that the early successional species G. ulmifolia exhibits higher photosynthetic plasticity than the late successional species $H$. courbaril.
\end{abstract}

Keywords: leaf gas exchange, light and $\mathrm{CO}_{2}$ photosynthetic responses, photosynthetic plasticity, plant ecophysiology, tropical forest succession.

\section{Evidências de maior plasticidade fotossintética na pioneira Guazuma ulmifolia Lam. comparada à secundária Hymenaea courbaril L. crescidas em ambientes luminosos contrastantes}

\section{Resumo}

O presente estudo investigou mudanças nas características fotossintéticas de Guazuma ulmifolia Lam. (pioneira) e Hymenaea courbaril L. (secundária) crescidas sob condições luminosas contrastantes, como uma maneira de acessar a plasticidade fotossintética das espécies. Espécies pioneiras geralmente habitam ambientes de clareira, expostas a uma ampla variação em múltiplos recursos, o que indica que essas espécies podem apresentar maior plasticidade fotossintética do que espécies secundárias. A fim de testar essa hipótese, foram feitas curvas de resposta à luz e ao $\mathrm{CO}_{2}$ e medidas do conteúdo de clorofila $(\mathrm{Chl})$ em plantas crescidas em ambientes com alta e baixa luminosidade. G. ulmifolia apresentou os maiores teores de $\mathrm{Chl} a$ e $b$, principalmente em baixa luminosidade, e ambas as espécies apresentaram maior conteúdo de clorofila $a$ do que $b$ em ambas as condições luminosas. A razão $\mathrm{Chl} a / b$ foi maior em folhas de sol em ambas as espécies e foi mais elevada em G. ulmifolia. Conjuntamente, esses resultados evidenciam um potencial de aclimatação em ambas as espécies, indicando a capacidade de modular os complexos antena 
de acordo com o ambiente luminoso. Contudo, G. ulmifolia mostrou evidências de maior plasticidade fotossintética, conforme indicado pela maior amplitude de variação nas características fotossintéticas entre ambientes, maior número de parâmetros significativamente justados à sombra (SAC) e pela análise de componentes principais (PCA). Assim, os resultados obtidos foram coerentes com a hipótese de que a espécie pioneira G. ulmifolia apresenta maior plasticidade fotossintética do que a secundária $H$. courbaril.

Palavras-chave: ecofisiologia vegetal, plasticidade fotossintética, respostas fotossintéticas à luz e ao $\mathrm{CO}_{2}$, sucessão florestal tropical, trocas gasosas foliares.

\section{Introduction}

In tropical forests, light availability affects plant succession and life-history strategies such as those of early and late successional species (Bazzaz and Pickett, 1980). Phenotypic plasticity is essential for survival in heterogeneous and variable environments, especially for sessile photosynthetic organisms (Sultan, 1992; Pintado et al., 1997). According to Chazdon et al. (1996) and Pigliucci (2001) phenotypic plasticity is usually defined as a property of individual genotypes to produce different phenotypes when exposed to different environmental conditions. Acclimation is, therefore, considered as a process by which plasticity is expressed.

Comparisons between early and late successional species suggest that these two groups generally exhibit different capacities for light acclimation (Björkman, 1981; Strauss-Debenedetti and Bazzaz, 1996; Valladares et al., 2000; Cai et al., 2005). Light acclimation is the process that allows environmentally induced changes in the photosynthetic utilisation of light, depending upon the irradiance regime under which leaves develop, involving a complex set of physiological, biochemical and structural responses that can increase the capacity to exploit light (Björkman, 1981). We consider, from here on, photosynthetic plasticity as a particular expression of phenotypic plasticity.

Photoacclimation can be considered on two levels: at the leaf and at the chloroplast level (Murchie and Horton, 1997). Chloroplast level acclimation refers to differences in content of thylakoid proteins, pigments, Calvin cycle enzymes, etc (Anderson et al., 1995; Murchie and Horton, 1997). Changes in parameters such as the chlorophyll $a / b$ ratio, the PSII/PSI ratio, or $\mathrm{A}_{\max }$ per unit of chlorophyll are indicative of chloroplast level acclimation. Leaf level acclimation refers to the markedly different anatomies of high and low light leaves: the 'sun-type' morphology would generally consist of thicker leaves with more columnar mesophyll cells (Sims and Pearcy, 1992; Oguchi et al., 2003). Leaf level acclimation seems to be largely controlled by signals perceived, generated in mature leaves and transduced to newly developing leaves, whereas chloroplast level acclimation is regulated by environmental events (Yano and Terashima, 2001; Oguchi et al., 2003). In leaves transferred from low to high light, successful light acclimation appears to be related to coordinated increases in both carboxylation and electron transport activity (Boardman, 1977; Langenheim et al., 1984; Thompson et al., 1992). High light acclimation is also associated with changes in chloroplast ultra-structure and increased chlorophyll $a / b$ ratios (Anderson et al., 1988).

Plasticity also occurs in within-leaf partitioning of resources between the two major functions of the photosynthetic apparatus in this context: light harvesting and $\mathrm{CO}_{2}$ assimilation capacity (Evans, 1989; Pons and Jordi, 1998). Photosynthetic performance is improved by investment in light harvesting, especially in low light conditions, and in $\mathrm{CO}_{2}$ assimilation, especially in highlight conditions (Evans and Seeman, 1989; Hikosaka and Terashima, 1996).

The potential of a given species to acclimate to environmental extremes is probably related to the pattern of environmental variability present in its habitat. Plants of open habitats have been described to respond plastically and acclimate rather quickly to changes in environmental conditions, such as temperature (Regehr and Bazzaz, 1978) and irradiance (Peterson and Bazzaz, 1978). Thus, it was suggested that early successional species would have higher photosynthetic plasticity relative to that of species found in later successional habitats (Bazzaz, 1979; Valladares et al., 2000; Ribeiro et al., 2005). However, increasing evidence indicates that both light-demanding and shade-tolerant species are capable of high photosynthetic plasticity, suggesting that high degree of adjustments to novel environmental conditions are not necessarily related to the species' successional status (Turnbull, 1991; Popma et al., 1992; Rozendaal et al., 2006; Souza et al., 2008).

The aim of the present study is to evaluate the plasticity of the photosynthetic responses of two species of different successional groups grown in contrasting light conditions. The multiple resource model proposed by Bazzaz and Pickett (1980) states that early successional species must be more plastic than late successional ones since they deal with variation in many resources. Thus, as an underlying hypothesis, we expect early successional species to show higher photosynthetic plasticity than late successional species.

\section{Material and Methods}

\subsection{Plant material and study site}

In this study we evaluated photosynthetic responses of young plants, approximately 120 days of age, of different ecological groups: Guazuma ulmifolia 
Lam. (Sterculiaceae) and Hymenaea courbaril L. (Leguminosae-Caesalpinoideae). The former woody species is an early successional and the latter is a late successional species (Lorenzi, 1992). The experiment was performed in an open area located at the Department of Biological Sciences, ESALQ/USP, Piracicaba, Brazil $\left(22^{\circ} 42^{\prime} \mathrm{S}\right.$ and $47^{\circ} 38^{\prime} \mathrm{W}, 546 \mathrm{~m}$ of altitude). Seeds of both species, donated by IPEF (Instituto de Pesquisas e Estudos Florestais - Forest Research and Study Institute), were germinated in a greenhouse and saplings of each species were later planted in 20 L pots, containing potting soil. Sixty days after germination, the pots were transferred to two different growth environments inside a greenhouse: 1 - high light (maximum PPFD around midday of $1800 \pm 200 \mu \mathrm{mol}$ photons $\mathrm{m}^{-2} / \mathrm{s}$ ) and 2- low light (around $50 \mu \mathrm{mol}$ photons $\mathrm{m}^{-2} / \mathrm{s}$ throughout the day). Plants were watered daily to full soil capacity and remained in the new environments for more 60 days. The photosynthetic measurements were performed only after this period. The shade environment was created with a black shade cloth of low transmittance.

\subsection{Determination of chlorophyll $a$ and $b$ concentrations}

Samples of the same leaf material used for gas exchange measurements were collected for chlorophyll content determination. Three leaf discs were sampled from different leaves of three plants and assays were carried out immediately after removal. Leaf discs were macerated and homogenised in a solution with DMF (dimethylformamide) and buffered aqueous acetone (80\%), pH 7.8. The homogenate was centrifuged at $14.000 \mathrm{rpm}$ for 5 minutes and the supernatants were submitted to measurements in a spectrophotometer at 663.6 and $646.6 \mathrm{~nm}$. The determination of chlorophyll concentration in the supernatant was performed according to equations described by Porra et al. (1989).

Chl $a=12.25 \times A^{663.6}-2.55 \times A^{646.6}$

Chl $b=20.31 \times A^{646.6}-4.91 \times A^{663.6}$

Chl $a+b=17.76 \times A^{646.6}-7.34 \times A^{663.6}$

where $A$ is the absorbance.

\subsection{Light and $\mathrm{CO}_{2}$ response curves}

Both light and $\mathrm{CO}_{2}$ response curves were taken using a portable infrared gas analyser (Li-6400, Li-Cor, Lincoln, NE, USA) with a leaf chamber of $6 \mathrm{~cm}^{2}$. Before the measurements the gas exchange system was zeroed using $\mathrm{CO}_{2}$-free and $\mathrm{H}_{2} \mathrm{O}_{\text {vapor }}$-free air. The air entering the gas analyser was sampled from a height of $2 \mathrm{~m}$ above ground and passed through a $10 \mathrm{~L}$ mixing volume before reaching the leaf chamber. The light and $\mathrm{CO}_{2}$ response curves were carried out from 8:00 AM to about 5:30 PM in healthy and fully developed leaves grown in both light environments. Three different plants per species were evaluated in each light environment.

In the light response curves, assimilation rate (A) was measured as a function of photosynthetic photon flux density (PPFD) in three fully expanded leaves for each species and light environment, under controlled temperature (about $27{ }^{\circ} \mathrm{C}$ ) and $\mathrm{CO}_{2}$ concentration $\left(400 \pm 1.2 \mu \mathrm{mol} . \mathrm{mol}^{-1}\right)$. Light response curves were performed from the highest $\left(2000 \mu \mathrm{mol}\right.$ photon $\left.\mathrm{m}^{-2} / \mathrm{s}\right)$ to the lowest PPFD (0), and data were recorded after assimilation rates reached the steady state. The $\mathrm{A}$ values at PPFD $=0$ were used as a measure of dark respiration (Rd). In the $\mathrm{CO}_{2}$ response curves, PPFD during measurements was set at $1200 \mu \mathrm{mol}$ photon $\mathrm{m}^{-2} / \mathrm{s}$ and $\mathrm{CO}_{2}$ concentration was decreased from $400 \mu \mathrm{mol} \mathrm{mol}{ }^{-1}$ until $50 \mu \mathrm{mol} \mathrm{mol}{ }^{-1}$ and then increased until $1900 \mu \mathrm{mol} \mathrm{mol}^{-1}$. Both light and $\mathrm{CO}_{2}$ response curves were fitted using the following equation (Prado and Moraes, 1997)

$$
A=A_{\max }\left(1-e^{-k(X-C P)}\right)
$$
where:

$\mathrm{A}=$ net $\mathrm{CO}_{2}$ assimilation

$\mathrm{A}_{\max }=$ maximum $\mathrm{CO}_{2}$ assimilation

$\mathrm{e}=$ Euler's number

$\mathrm{k}=$ constant related to the convexity of the curve

$\mathrm{X}=\mathrm{PPFD}$ or $\mathrm{Ci}$

$\mathrm{CP}=$ Light or $\mathrm{CO}_{2}$ compensation point

Light and $\mathrm{CO}_{2}$ saturation points were estimated calculating the $\mathrm{X}$-axis values in which A reached $90 \%$ of $\mathrm{A}_{\max }$. Apparent quantum and carboxylation efficiencies were estimated using the initial linear slope of $A \times$ PPFD and $\mathrm{A} \times \mathrm{Ci}$ curves respectively. Relative stomatal limitation of photosynthesis (Ls) was calculated as proposed by Farquhar and Sharkey (1982):

$$
\mathrm{Ls}=\left[\left(\mathrm{A}^{\prime}-\mathrm{A}\right) / \mathrm{A}^{\prime}\right]^{*} 100
$$

where:

$\mathrm{A}^{\prime}=\mathrm{CO}_{2}$ assimilation when $\mathrm{Ci}$ equals the atmosphere concentration

$\mathrm{A}=\mathrm{CO}_{2}$ assimilation when Ce equals the atmosphere concentration

Water use efficiency (WUE) $\left(\mathrm{mmol} \mathrm{CO}_{2} \mathrm{~mol} \mathrm{H}_{2} \mathrm{O}^{-1}\right)$ was calculated dividing daily integrated $\mathrm{A}$ values by integrated $\mathrm{E}$ values obtained in daily courses (data not show).

The shade adjustment coefficient (SAC) was calculated as in Laisk et al. (2005):

$\mathrm{SAC}=1-($ Shade/Sun $)$

where shade and sun corresponds to the value of a given physiological parameter in each respective environment. This is an estimate of shade adjustment, where higher absolute values of SAC indicate higher photosynthetic plasticity in response to different light conditions. SAC was considered significant depending on the results of a t-test performed between sun and shade values, at 5\% significance level.

\subsection{Statistical analysis}

All data were subjected to a two-way-ANOVA, in order to test the significance of the differences between species in each light condition and between light conditions for each species. Pos hoc average comparisons were performed by Tukey's test at 5\% significance level. Analyses were carried out using Sisvar 4.6 software. 
Multivariate principal components analysis (PCA) was used in order to evaluate the combination of photosynthetic characteristics of the species studied in both environments. The PCA is a linear dimensionality reduction technique, which identifies orthogonal directions of maximum variance in the original data, projecting the data into a lower-dimensionality space formed by a subset of the highest-variance components (Manly, 1994). In this study a space of two dimensions (two principal components), which were limited by two axes labelled pc1 and pc2, was suitable for our analysis. In this analysis, all parameters presented in Table 1 were used, except Chl contents, and the threshold established to consider a given physiological parameter relevant for each axis was 0.35 (eigenvector). The analysis was performed on PC-ORD version 3.12 software (MJM Software Design, Gleneden Beach, Oregon, USA).

\section{Results and Discussion}

\subsection{Chlorophyll content}

The early successional species G. ulmifolia presented the highest contents of both Chl $a$ and $b$ and total Chl $(a+b)$ especially in the low light environment (Table 1). Previous works also described that $\mathrm{Chl}$ is higher in leaves of shade plants relative to sun plants (Anderson et al., 1988; Evans, 1989; Zhang et al., 1995; Feng et al.,
2004). Shade-acclimated leaves contain higher Chl per unit of mass than sun leaves, which is related to increased allocation of resources to light-harvesting functions rather than in electron transport and $\mathrm{CO}_{2}$ fixation capacity (Björkman, 1981; Walters, 2005). However, in $H$. courbaril the highest $\mathrm{Chl}$ contents $(a, b$ and total) were detected in leaves under high light conditions. Since higher SLW is expected in high light grown leaves (Krall et al., 1995; Murchie and Horton, 1997; Portes et al., 2006), this unexpected result can be explained by the differences between leaf thickness in sun and shade leaves. Lichtenthaler et al. (2007) also verified higher total Chl $(a+b)$ contents per unit of leaf area in sun leaves and needles in the four tree species studied; however when expressed on a dry matter basis, shade leaves and needles presented higher Chl $a+b$ content.

G. ulmifolia and $H$. courbaril presented higher content of Chl $a$ than $b$ in both high and low light conditions, although in $H$. courbaril the contents were higher in high light leaves of and in G. ulmifolia in low light leaves. However, the $\mathrm{Chl} a / b$ ratio was higher in high light leaves of the both species, being the highest in G. ulmifolia. Other studies described that $\mathrm{Chl} a / b$ ratio is higher in sun plants than in shade plants for many species (Anderson, 1986; Sims and Pearcy, 1989; Zhang et al., 1995). Acclimation to shade conditions has been shown to result in decreased $\mathrm{Chl} a / b$ ratio reflecting

Table 1. Photosynthetic parameters of Guazuma ulmifolia and Hymenaea courbaril in high and low light environments. Capital letters mean statistical differences between species whereas small letters mean statistical differences between light environments. Bolded shade adaptation coefficient $(\mathrm{SAC})$ values indicate significative differences $(\mathrm{p}<0.05)$ between environments within the same species $(\mathrm{n}=3) . \alpha=$ apparent quantum efficiency $\left(\mu \mathrm{mol} \mathrm{CO}_{2}(\mu \mathrm{mol} \text { photon })^{-1}\right), \varepsilon=$ apparent carboxylation efficiency $\left(\mu \mathrm{mol} \mathrm{CO} \mathrm{m}^{-2} / \mathrm{s} \mathrm{Pa}^{-1}\right), \mathrm{LCP}=$ light compensation point $\left(\mu \mathrm{mol}\right.$ photon $\left.\mathrm{m}^{-2} / \mathrm{s}\right), \mathrm{LSP}=$ light saturation point $\left(\mu \mathrm{mol}\right.$ photon $\left.\mathrm{m}^{-2} / \mathrm{s}\right), \mathrm{Rd}=$ dark respiration $\left(\mu \mathrm{mol} \mathrm{CO} \mathrm{m}^{-2} / \mathrm{s}\right), A_{\max }=$ maximum $\mathrm{CO}_{2}$ assimilation $\left(\mu \mathrm{mol} \mathrm{CO}_{2} \mathrm{~m}^{-2} / \mathrm{s}\right)$, $\mathrm{CCP}=\mathrm{CO}_{2}$ compensation point $\left(\mu \mathrm{mol} \mathrm{CO} \mathrm{mol}^{-1}\right), \mathrm{CSP}=\mathrm{CO}_{2}$ saturation point $\left(\mu \mathrm{mol} \mathrm{CO} \mathrm{mol}^{-1}\right), \mathrm{Ls}=$ relative stomatal limitation of photosynthesis $(\%), \mathrm{Chl}=$ chlorophyll content $\left(\mu \mathrm{g} \cdot \mathrm{cm}^{-2}\right), \mathrm{WUE}=$ water use efficiency $\left(\mathrm{mmol} \mathrm{CO}_{2} \mathrm{~mol} \mathrm{H}_{2} \mathrm{O}^{-1}\right)$.

\begin{tabular}{|c|c|c|c|c|c|c|}
\hline \multirow[t]{3}{*}{ Parameter } & \multicolumn{6}{|c|}{ Species } \\
\hline & \multicolumn{3}{|c|}{ G. ulmifolia } & \multicolumn{3}{|c|}{ H.courbaril } \\
\hline & High light & Low light & SAC & High light & Low light & SAC \\
\hline Chl a & $2.37 \pm 0.28^{\mathrm{Aa}}$ & $2.70 \pm 0.18^{\mathrm{Aa}}$ & -0.14 & $1.67 \pm 0.28^{\mathrm{Ba}}$ & $0.9625 \pm 0.12^{\mathrm{Bb}}$ & 0.42 \\
\hline Chl b & $0.59 \pm 0.05^{\mathrm{Ab}}$ & $0.88 \pm 0.08^{\mathrm{Aa}}$ & -0.49 & $0.55 \pm 0.08^{\mathrm{Aa}}$ & $0.39 \pm 0.05^{\mathrm{Ba}}$ & 0.29 \\
\hline Chl a+b & $2.96 \pm 0.33^{\mathrm{Aa}}$ & $3.58 \pm 0.26^{\mathrm{Aa}}$ & -0.21 & $2.22 \pm 0.36^{\mathrm{Aa}}$ & $1.35 \pm 0.15^{\mathrm{Bb}}$ & 0.39 \\
\hline $\mathrm{Chl} \mathrm{a/b}$ & $3.96 \pm 0.18^{\mathrm{Aa}}$ & $3.12 \pm 0.15^{\mathrm{Ab}}$ & 0.21 & $3.03 \pm 0.14^{\mathrm{Ba}}$ & $2.56 \pm 0.33^{\mathrm{Aa}}$ & 0.16 \\
\hline$\alpha$ & $0.04 \pm 0.001^{\mathrm{Aa}}$ & $0.034 \pm 0.001^{\mathrm{Ab}}$ & 0.16 & $0.017 \pm 0.000^{\mathrm{Ba}}$ & $0.014 \pm 0.002^{\mathrm{Ba}}$ & 0.16 \\
\hline $\mathrm{A}_{\max }$ light & $15.13 \pm 0.38^{\mathrm{Aa}}$ & $4.65 \pm 0.19^{\mathrm{Ab}}$ & 0.69 & $4.46 \pm 0.09^{\mathrm{Aa}}$ & $3.80 \pm 0.18^{\mathrm{Aa}}$ & 0.15 \\
\hline LCP & $10.03 \pm 1.52^{\mathrm{Aa}}$ & $1.92 \pm 0.87^{\mathrm{Ab}}$ & 0.81 & $11.97 \pm 3.26^{\mathrm{Aa}}$ & $4.29 \pm 0.60^{\mathrm{Ab}}$ & 0.64 \\
\hline LSP & $679.95 \pm 32.56^{\mathrm{Aa}}$ & $192.52 \pm 14.32^{\mathrm{Ab}}$ & 0.72 & $436.24 \pm 52.32^{\mathrm{Aa}}$ & $344.6 \pm 94.44^{\mathrm{Aa}}$ & 0.21 \\
\hline $\mathrm{Rd}$ & $0.75 \pm 0.04^{\mathrm{Aa}}$ & $0.19 \pm 0.05^{\mathrm{Ab}}$ & 0.74 & $0.50 \pm 0.10^{\mathrm{Ba}}$ & $0.24 \pm 0.03^{\mathrm{Ab}}$ & 0.52 \\
\hline$\varepsilon$ & $0.07 \pm 0.01^{\mathrm{Aa}}$ & $0.03 \pm 0.002^{\mathrm{Ab}}$ & 0.57 & $0.03 \pm 0.003^{\mathrm{Aa}}$ & $0.02 \pm 0.001^{\mathrm{Aa}}$ & 0.45 \\
\hline $\mathrm{A}_{\max } \mathrm{CO}_{2}$ & $27.42 \pm 0.39^{\mathrm{Aa}}$ & $10.66 \pm 0.36^{\mathrm{Ab}}$ & 0.61 & $13.44 \pm 0.96^{\mathrm{Ba}}$ & $7.67 \pm 0.68^{\mathrm{Bb}}$ & 0.43 \\
\hline $\mathrm{CCP}$ & $52.81 \pm 0.57^{\mathrm{Ba}}$ & $67.94 \pm 4.28^{\mathrm{Aa}}$ & -0.29 & $90.72 \pm 8.39^{\mathrm{Aa}}$ & $69.29 \pm 5.57^{\mathrm{Ab}}$ & 0.24 \\
\hline CSP & $614.42 \pm 0.57^{\mathrm{Ba}}$ & $622.78 \pm 4.29^{\mathrm{Ba}}$ & -0.01 & $812.53 \pm 8.4^{\mathrm{Ab}}$ & $836.81 \pm 5.57^{\text {Аа }}$ & -0.03 \\
\hline Ls & $19.69 \pm 2.55^{\mathrm{Ba}}$ & $25.88 \pm 3.60^{\mathrm{Aa}}$ & -0.31 & $40.37 \pm 8.31^{\mathrm{Aa}}$ & $18.28 \pm 6.48^{\mathrm{Ab}}$ & 0.55 \\
\hline WUE & $7.3^{\mathrm{Ba}}$ & $0.34^{\mathrm{Bb}}$ & 0.95 & $7.7^{\mathrm{Aa}}$ & $2.07^{\mathrm{Ab}}$ & 0.73 \\
\hline
\end{tabular}


changes in concentrations of light-harvesting Chl complexes relative to reaction centres (Anderson, 1986; Walters, 2005). Decreased $\mathrm{Chl} a / b$ ratio in the shade results from greater investment in light-harvesting $\mathrm{Chl} a / b$ protein complexes of photosystem II (LHCP-II), which contain most of the $\mathrm{Chl} b$ in the chloroplast (Anderson, 1986). The capacity to increase the investment in $\mathrm{Chl}$ in general and particularly in LHCP-II appears to be greater in shade tree species as compared to sun-adapted species (Chu and Anderson, 1984; Evans, 1989). The lower $\mathrm{Chl} a / b$ ratio results from increased LHCP-II per unit of leaf area coupled with decreased concentrations of PSII core complex (Evans, 1986). The shift to more LHCPII while maintaining constant the total $\mathrm{Chl}$ per unit of leaf area results in a significantly greater light capture per unit of $\mathrm{N}$ invested, which is possible in shade but not in sun leaves, since high capacities of PSII electron transport are not needed in shade conditions (Nilsen and Orcutt, 1996).

Taken together these results evidence the acclimation potential of both species, reflecting the capacity to modulate light harvesting complexes according to the light environment. Given that $\mathrm{Chl}$ content is a highly plastic characteristic, it did not provide clear insights of potential differences in photosynthetic plasticity between species.

\subsection{Light and $\mathrm{CO}_{2}$ response curves}

Comparing the light response curves between environments, G. ulmifolia showed a remarkably higher A rate under high light, while $H$. courbaril did not show significant difference between light environments (Figure 1 and Table 1), indicating lower photosynthetic plasticity in the late successional species (Ribeiro et al., 2005). Comparing between species, G. ulmifolia presented higher $\mathrm{A}_{\max }(\mathrm{p}<0.05)$ than $H$. courbaril in both environments (Table 1). The apparent quantum efficiency $(\alpha)$ was significantly higher in $G$. ulmifolia than in $H$. courbaril in both environments $(\mathrm{p}<0.05)$ (Table 1$)$. The $\alpha$ values did not show significant differences between environments in $H$. courbaril ( $\mathrm{p}>0.05$ ), which is expected since quantum yield tends to remain insensitive to the light environment (Björkman, 1981; Sims and Pearcy, 1989; Ramos and Grace, 1990; Valladares et al., 1997). However, G. ulmifolia showed a significantly lower $\alpha(\mathrm{p}<0.05)$ in shade conditions. Laisk et al. (2005) discusses that alterations in the LHC may decrease the quantum efficiency in shade adjusted leaves, but not increase it. Björkman (1981), studying plants under severe protein $\mathrm{N}$ deficiency, reported that the adaptational goal of the light-harvesting machinery seems to be to maintain Chl organised around PSII. This strategy ensures the maximum possible quantum yield at low light, possibly explaining the difference in quantum yield observed in G. ulmifolia.

Photosynthetic light compensation point (LCP) did not show significant differences ( $p>0.05$ ) between species in both light environments (Table 1), although the


Figure 1. Photosynthetic light response curves of $\mathrm{CO}_{2}$ assimilation in Guazuma ulmifolia and Hymenaea courbaril under high light $(\circ)$ and low light environments $(\bullet)$. Vertical lines represent \pm standard error $(n=3)$.

mean values were higher in the high light for both species ( $\mathrm{p}<0.05)$. Langenheim et al. (1984) also verified that $H$. courbaril presented lower LCP when grown in the shade. In general, early successional plants have high LCP and high rates of $\mathrm{A}_{\max }$ (Bazzaz and Pickett, 1980; Feng et al., 2004). Taiz and Zeiger (1998) suggested that LCP of sun plants range from 10 to $20 \mu \mathrm{mol}$ photon $\mathrm{m}^{-2} / \mathrm{s}$, and of shade plants from 1 to $5 \mu \mathrm{mol}$ photon $\mathrm{m}^{-2} / \mathrm{s}$. The values for shade plants are lower because respiration rates are very low, therefore small assimilation rates are sufficient to bring the rates of $\mathrm{CO}_{2}$ evolution to zero. Low respiratory rates seem to represent a basic adaptation that allows shade plants to survive in light-limited environments, since it is of utmost importance to minimise carbon losses via respiration in order to maintain a positive net carbon balance in highly shaded environments (Givnish, 1988; Reich et al. 1998; Pearcy, 1998).

Both species showed greater values of dark respiration ( $\mathrm{Rd}$ ) in the high light compared to the low light ( $\mathrm{p}<0.05$ ), being significantly higher in G. ulmifolia than in $H$. courbaril only in high light (Table 1$)$. Several authors also verified that respiration rates are higher in the sun (forest gap environments) than in the shade (understorey) (Ramos and Grace, 1990; Fredeen and Field, 
1991; Feng et al., 2004). As we observed in the high light, it has been described that early successional species usually show higher leaf respiration than late successional ones (Bazzaz and Pickett, 1980; Chazdon et al., 1996). The higher Rd in sun plants may be a combined result of higher energy cost for maintenance and greater availability of carbohydrates due to higher assimilation rates (Sims and Pearcy, 1991).

Comparing between species, the light saturation point (LSP) did not show significant differences $(p>0.05)$ in both environments (Table 1). However, LSP was higher in $G$. ulmifolia under high light, being significantly different $(\mathrm{p}<0.05)$ between environments only in this species. Previous studies found that the level of irradiance required for photosynthetic saturation is lower for late successional species (Bazzaz, 1979; Bazzaz and Pickett, 1980), which was not observed here since G. ulmifolia lowered considerably its LSP. This is an indication of high photosynthetic plasticity in the early successional species.

Concerning $\mathrm{CO}_{2}$ response curves (Figure 2), as observed in the light response curves, G. ulmifolia pre-
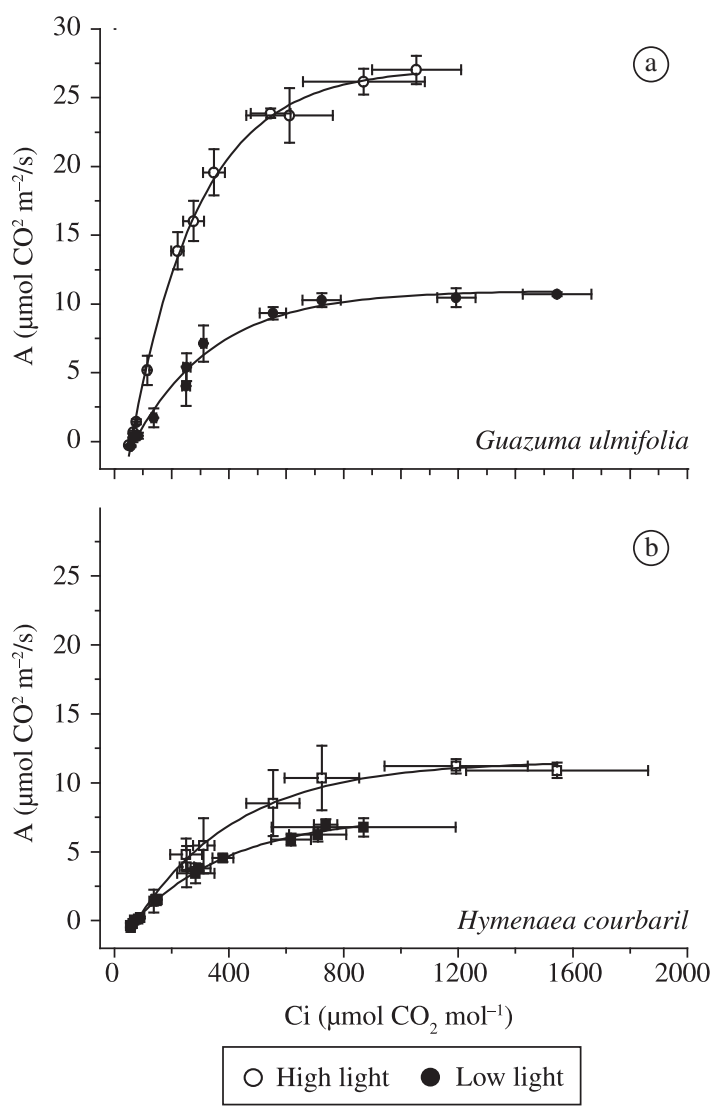

Figure 2. Intercellular $\mathrm{CO}_{2}$ concentration (Ci) response curves of $\mathrm{CO}_{2}$ assimilation in Guazuma ulmifolia and Hymenaea courbaril under high light (०) and low light environments $(\bullet)$. Vertical and horizontal lines represent \pm standard error $(n=3)$. sented higher $(\mathrm{p}<0.05) \mathrm{A}_{\max }$ rates than $H$. courbaril in both environments (Figure 2, Table 1). The apparent carboxylation efficiency $(\varepsilon)$ was not significantly different $(\mathrm{p}>0.05)$ between species as well as between light environments for $H$. courbaril. However, $\varepsilon$ was significantly higher $(\mathrm{p}<0.05)$ in the high light for $G$. ulmifolia. Comparing species, $\mathrm{CO}_{2}$ compensation point (CCP) was significantly higher $(\mathrm{p}<0.05)$ in $H$. courbaril in the high light but did not show significant differences $(p>0.05)$ in the low light. The difference between light environments was significant only in $H$. courbaril which presented higher $\mathrm{CCP}$ in the high light. The $\mathrm{CO}_{2}$ saturation point (CSP) did not change ( $p>0.05)$ between light environments in G. ulmifolia, but was significantly higher in $H$. courbaril in the low light $(\mathrm{p}<0.05)$. Comparing species, CSP was significantly higher $(\mathrm{p}<0.05)$ in $H$. courbaril in both light environments (Table 1).

In terms of potential performance, the data on light and $\mathrm{CO}_{2}$ response curves indicate that $G$. ulmifolia has greater efficiency in light exploitation than $H$. courbaril in both light environments.

H. courbaril presented significantly higher $(\mathrm{p}<0.05)$ relative stomatal limitation of photosynthesis (Ls) than G. ulmifolia under high light (Table 1). Both species significantly adjusted its Ls to low light conditions $(\mathrm{p}<0.05)$ as indicated by SAC value (Table 1$)$. In high light conditions, both species showed similar WUE $(p>0.05)$, which was significantly higher $(p<0.05)$ than in the low light (Table 1). This parameter was dramatically different in the shade, given that $H$. courbaril presented a considerably higher WUE than G. ulmifolia.

The higher variation between environments observed in light and $\mathrm{CO}_{2}$ response curves in G. ulmifolia compared to $H$. courbaril indicates that the photosynthetic apparatus of the former species can respond more plastically to different light conditions. $H$. courbaril showed similar performances under high and low light conditions, indicating lower plasticity for the traits analysed.

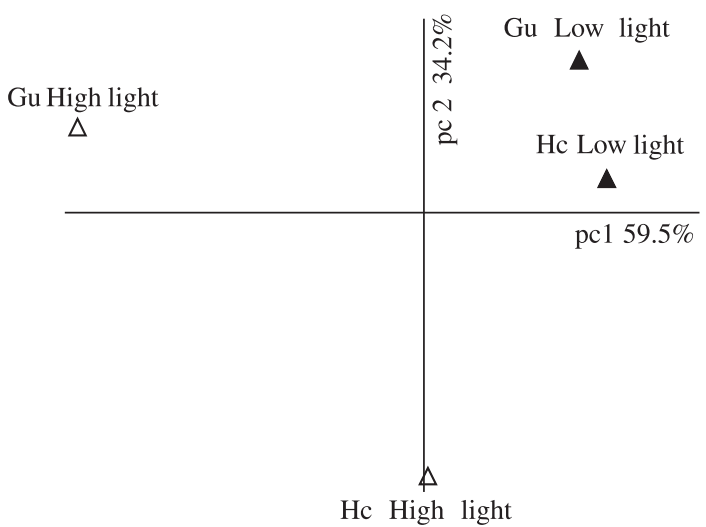

Figure 3. Ordination graph of principal component analysis (PCA) of species Guazuma ulmifolia $(\mathrm{Gu})$ and Hymenaea courbaril $(\mathrm{Hc})$ in high light $(\boldsymbol{\Delta})$ and in low light environment $(\circ)$, for first and second principal components (pc1 and $\mathrm{pc} 2$ axes, respectively). 
Table 2. Eigenvectors of the physiological parameters corresponding to pc (principal component) 1 and 2 axes considered in principal component analysis (PCA).

\begin{tabular}{ccccc}
\hline \multicolumn{2}{c}{ pc1 } & & \multicolumn{2}{c}{ pc2 } \\
\cline { 1 - 2 } Physiological parameters & Eigenvectors values & & Physiological parameters & Eigenvector values \\
\hline $\mathrm{A}_{\max } \mathrm{CO}_{2}$ & 0.371 & $\mathrm{CSP}$ & 0.420 \\
$\mathrm{Rd}$ & 0.362 & $\mathrm{CCP}$ & 0.416 \\
$\varepsilon$ & 0.359 & $\mathrm{Ls}$ & 0.409 \\
$\mathrm{~A}_{\max }$ light & 0.357 & $\mathrm{LCP}$ & 0.366 \\
$\mathrm{LSP}$ & 0.349 & $\mathrm{WUE}$ & 0.322 \\
$\mathrm{WUE}$ & 0.283 & $\alpha$ & 0.321 \\
$\alpha$ & 0.261 & $\mathrm{~A}_{\max }$ light & 0.145 \\
$\mathrm{LCP}$ & 0.251 & $\mathrm{Rd}$ & 0.121 \\
$\mathrm{CCP}$ & 0.184 & $\varepsilon$ & 0.120 \\
$\mathrm{CSP}$ & 0.125 & $\mathrm{LSP}$ & 0.090 \\
$\mathrm{Ls}$ & 0.042 & $\mathrm{~A}_{\max } \mathrm{CO}_{2}$ & 0.054 \\
\hline
\end{tabular}

Considering that SAC indicates the capacity to adjust to shade conditions, more significant shade adjusted parameters presented by $G$. ulmifolia suggest higher capacity to acclimate to different conditions (Table 1). Since acclimation can be seen as a process by which plasticity is expressed, higher plasticity may also be attributed to G. ulmifolia. This is in agreement with several studies which reported higher plasticity in light-demanding species (Valladares et al., 2000; Feng et al., 2004, Ribeiro et al., 2005, Souza et al., 2008).

The distribution obtained in principal component analysis (PCA) showed that the first principal component (pc1) accounted for $59.5 \%$ of the total variance present in the data, while the second principal component (pc2) accounted for $34.2 \%$ of the variance, with a total of $93.7 \%$ of the variance explained by both axes (Figure 3 ). The physiological parameters of greater significance for the separation of species in the different environments, according to eigenvector values (Table 2), in relation to $\mathrm{pc} 1$ axis were: $\mathrm{A}_{\max } \mathrm{CO}_{2}, \mathrm{Rd}, \varepsilon$ and $\mathrm{A}_{\max }$ light. With respect to pc2 axis, the physiological parameters of greater significance were: CSP, CCP, Ls and LCP. The PCA showed a clear separation among the species and environments. The plants grown in low light were grouped whereas high light plants remained further apart. Considering only pc1, it is possible to verify that the distance between low and high light grown plants is lower in $H$. courbaril than in G. ulmifolia, meaning that there is much more variation due to the difference in environments in G. ulmifolia than in $H$. courbaril. The pc2 accounted for the separation of $H$. courbaril in the high light from plants grown in the low light representing an evidence of acclimation to this environment, as suggested by changes principally in CSP and CCP and also in LCP and Ls (Figure 3).

Considering these results, the early successional species G. ulmifolia is apparently capable of higher photosynthetic plasticity, since it showed greater capacity to acclimate by changing its photosynthetic characteristics between environments. Conversely, $H$. courbaril has a more conservative response to environmental changes, which probably constitute a different strategy compatible with its successional status (Valladares, 2004). These indications are based solely on the plasticity of the traits evaluated herein, which is limited since photosynthetic plasticity is a processes occurring at the whole-plant level. Plasticity is also conditioned on seasonality, being particularly pronounced in the gap environment, as well as on other environmental factors (Souza et al., 2008).

\section{Conclusion}

The data presented in this study support the hypothesis that early successional species are capable of higher acclimation and thus displays higher photosynthetic plasticity. As expected, G. ulmifolia showed, in general, higher photosynthetic potential performance under high light and low light conditions. H. courbaril, however, showed higher WUE and lower Ls under low light condition, agreeing with the physiological characteristics attributed to its ecological group. Results obtained by SAC and PCA analyses indicated that G. ulmifolia showed higher capacity to adjust its physiological parameters to contrasting light environments, having greater amplitude of variation in photosynthetic characteristics which indicates higher photosynthetic plasticity. It is important to keep in mind that these parameters and analyses may not be sufficient to assess phenotypic plasticity completely, which is a characteristic of the whole-plant level that may be expressed in different scales of spatial-temporal organization.

Acknowledgements - We thank Dr. Carlos Labate (ESALQUSP) for the chlorophyll content analyses, FAPESP (Fundação de Amparo à Pesquisa do Estado de São Paulo) and CAPES (Coordenação de Aperfeiçoamento de Pessoal de Nível Superior) for financial support. 


\section{References}

ANDERSON, JM. 1986. Photoregulation of the composition, function, and structure of thylakoid membranes. Annual Review of Plant Physiology, vol. 37, p. 93-136.

ANDERSON, JM., CHOW, WS. and GOODCHILD, DJ. 1988. Thylakoid membrane organization in sun/shade acclimation. Australian Journal of Plant Physiolpgy, vol. 15, p. 11-26.

ANDERSON, JM., CHOW, WS. and PARK, YI. 1995. The grand design of photosynthesis: acclimation of the photosynthetic apparatus to environmental cues. Photosynthesis Research, vol. 46, no. 1-2, p. 129-139.

BAZZAZ, FA. 1979. The physiological ecology of plant succession. Annual Review of Ecology and Systematics, vol. 10, p. 351-371.

BAZZAZ, FA. and PICKETT, STA. 1980. Physiological ecology of tropical succession: A comparative review. Annual Review of Ecology and Systematics, vol. 11, p. 287-310.

BJÖRKMAN, O. 1981. Responses to different quantum flux densities. In: LANGE, OL., NOBLE, PS., OSMOND, CB. and ZEIGER H. (Eds.). Encyclopedia of Plant Physiology (New Series). Physiological Ecology I. Vol 12A. New York: Springer. p. $57-102$.

BOARDMAN, NK. 1977. Comparative photosynthesis of sun and shade plants. Annual Review of Plant Physiology, vol. 28, p. $355-377$.

CAI, ZQ., RIJKERS, T. and BONGERS, F. 2005. Photosynthetic acclimation to light changes in tropical monsoon forest wood species differing in adult stature. Tree Physiology, vol. 25, p. $1023-1031$.

CHAZDON, RL., PEARCY, RW., LEE, DW. and FETCHER, N. 1996. Photosynthetic responses of tropical forest plants to contrasting light environments. In MULKEY, SS., CHAZDON, RL. and SMITH,AP.(Eds.). Tropical Forest Plant Ecophysiology. New York: Chapman and Hall. p. 5-55.

CHU, ZX. and ANDERSON, JM. 1984. Modulation of the light harvesting assemblies in chloroplast of a shade plant, Alocasia macrorrniza. Photobiochemestry and Photobiophysics, vol. 8, p. 1-10.

EVANS, JR. 1986. A quantitative analysis of light distribution between the two photosystems, considering variation in both the relative amounts of the chlorophyll-protein complexes and the spectral quality of light. Photobiochemestry and Photobiophysics, vol. 10, p. 135-147.

1989. Photosynthesis - The dependence on nitrogen partitioning. In LAMBERS, H., CAMBRIDGE, ML., KONINGS, H. and PONS, TL. (Eds.). Causes and Consequences of Variation in Growth Rate and Productivity of Higher Plants. The Netherlands: SPB Academic Publishing. p. 159-174.

EVANS, JR. and SEEMANN, JR. 1989. The allocation of protein nitrogen in the photosynthetic apparatus: costs, consequences, and control. In: Briggs, W. and ALAN, R. (Eds.). Towards a broad understanding of photosynthesis. New York: Alan R. Liss. p. 183-205.

FARQUHAR, GD. and SHARKEY, TD. 1982. Stomatal conductance and photosynthesis. Annual Review of Plant Physiology, vol. 33, p. 317-345.
FENG, YL., CAO, KF. and ZHANG, JL. 2004. Photosynthetic characteristics, dark respiration, and leaf mass per unit area in seedlings of four tropical tree species grown under three irradiances. Photosynthetica, vol. 42, p. 431-437.

FREDEEN, AL. and FIELD, CB. 1991. Leaf respiration in Piper species native to a Mexican rainforest. Physiologia Plantarum, vol. 82 , no. 1, p. 85-92.

GIVNISH, TJ. 1988. Adaptation to sun and shade: a wholeplant perspective. Australian Journal of Plant Physiology, vol. 15 , no. 2 , p. 63-92.

HIKOSAKA, K. and TERASHIMA, I. 1996. Nitrogen partitioning among photosynthetic components and its consequence in sun and shade plants. Functional Ecology, vol. 10, p. 335-343.

KRALL, JP., SHEVELEVA, EV. and PEARCY, RW. 1995. Regulation of photosynthetic induction state in high- and lowlight-grown soybean and Alocasia macrorrhiza (L.) G. Don. Plant Physiology, vol. 109, no. 1, p. 307-317.

LAISK, H., EICHELMANN, V., OJA, B., RASUlOV, E., PADU, I., BICHELE, H. and PETTAI, O. 2005. Adjustment of leaf photosynthesis to shade in a natural canopy: rate parameters. Plant, Cell and Environment, vol. 28, no. 3, p. 375-388.

LANGENHEIM, JH., OSMOND, CB., BROOKS, A. and FERRAR, PJ. 1984. Photosynthetic responses to light in seedlings of selected Amazonian and Australian rainforest tree species. Oecologia, vol. 63, no. 2, p. 215-224.

LICHTENTHALER, HK., AČ, A., MAREK, MV., KALINA, J. and URBAN, O. 2007. Differences in pigment composition, photosynthetic rates and chlorophyll fluorescence images of sun and shade leaves of four tree species. Plant Physiologyand Biochemestry, vol. 45, no. 8, p. 577-588.

LORENZI, H. 1992.Árvores brasileiras: manual de identificação e cultivo de plantas arbóreas nativas do Brasil. Nova Odessa: Plantarum. 352 p.

MANLY, BFJ. 1994. Multivariate statistical methods. London: Chapman and Hall. 232 p.

MURCHIE, EH. and HORTON, P. 1997. Acclimation of photosynthesis to irradiance and spectral quality in British plant species: chlorophyll content, photosynthetic capacity and habitat preference. Plant, Cell and Environment., vol. 20, no. 4, p. 438-448.

NILSEN, ET. and ORCUTT, DM. 1996. Physiology of Plants Under Stress. Abiotic Factors. New York: John Wiley and Sons. $689 \mathrm{p}$.

OGUCHI, R., HIKOSAKA, K. and HIROSE, T. 2003. Does the change in light acclimation need leaf anatomy? Plant, Cell and Environment, vol. 26, no. 4, p. 505-512.

PEARCY, RW. 1998. Acclimation to sun and shade. In RAGHAVENDRA, AS. (Ed.). Photosynthesis - A Comprehensive Treatise. Cambridge: Cambridge University Press. p. 250-263.

PETERSON, DL. and BAZZAZ, FA. 1978. Life cycle characteristics of Aster pilosus in early successional habitats. Ecology, vol. 59, no. 5, p. 1005-1013.

PIGLIUCCI, M. 2001. Phenotypic Plasticity. In FOX, CW., ROFF, DA. and Fairbairn, DJ. (Eds.). Evolutionary Ecology: Concepts and Case Studies. Oxford: University Press. p. 58-69. 
PINTADO, A., VALLADARES, F. and SANCHO, LG. 1997. Exploring phenotypic plasticity in the lichen Ramalina capitata: morphology, water relations and chlorophyll content in northand south-facing populations. Annals of Botany, vol. 80, no. 3, p. $345-353$

PONS, TL. and JORDI, W. 1998. Induction of leaf senescence and shade acclimation in leaf canopies-variation with leaf longevity. In LAMBERS, H., POORTER, H., VAN VUUREN, MMI. (Eds.). Inherent variation in plant growth: physiological mechanisms and ecological consequences. Leiden: Backhuys Publishers. p. 121-137.

POPMA, J., BONGERS, F. and WERGER, MJA. 1992. Gapdependence and leaf characteristics of trees in a tropical rain forest in Mexico. Oikos, vol. 63, p. 207-214.

PORRA, RJ., THOMPSON, WA. and KRIEDEMANN, PE. 1989. Determination of accurate extinction coefficients and simultaneous equations for assaying chlorophylls a and b extracted with four different solvents: verification of the concentration of chlorophyll standards by atomic absorption spectroscopy. Biochimica et Biophysica Acta, vol. 975, no. 3, p. $384-394$

PORTES, MT., ALVES, TH. and SOUZA, GM. 2006. Water deficit affects photosynthetic induction in Bauhinia forficata Link (Fabaceae) and Esenbeckia leiocarpa Engl. (Rutaceae) growing in understorey and gap conditions. Brazilian Journal of Plant Physiology, vol. 18, no. 4, p. 465-474.

PRADO, CHBA. and MORAES, JAPV. 1997. Photosynthetic capacity and specific leaf mass in twenty woody species of cerrado vegetation under field conditions. Photosynthetica, vol. 33 , no. 1 , p. 103-112.

RAMOS, J. and GRACE, J. 1990. The effects of shade on the gas exchange of seedlings of four tropical trees from Mexico. Functional Ecology, vol. 4, no. 5, p. 667-677.

REGEHR, DL. and BAZZAZ, FA. 1978. Low temperature photosynthesis in successional winter annuals. Ecology, vol. 57, no. 6, p. 1297-1303.

REICH, PB., WALTERS, MB., TJOELKER, MG., VANDERKLEIN, D. and BUSCHENA, C. 1998. Photosynthesis and respiration rates depend on leaf and root morphology and nitrogen concentration in nine boreal tree species differing in relative growth rate. Functional Ecology, vol. 12, no. 3, p. $395-405$.

RIBEIRO, RV., SOUZA, GM., OLIVEIRA, RF. and MACHADO, EC. 2005. Photosynthetic responses of tropical tree species from different successional groups under contrasting irradiance conditions. Revista Brasileira de Botânica, vol. 28, no. 1, p. 149-161.

ROZENDAAL, DMA., HURTADO, VH. and POORTER, L. 2006. Plasticity in leaf traits of 38 tropical tree species in response to light; relationship with light demand and adult stature. Functional Ecology, vol. 20, p. 207-216.

SIMS, DA. and PEARCY, RW. 1989. Photosynthetic characteristics of a tropical forest understory herb, Alocasia macrorrhiza, and a related crop species, Colocasia esculenta grown in contrasting light environments. Oecologia, vol. 79, no. 1, p. 53-59.

SIMS, DA. and PEARCY, RW. 1991. Photosynthesis and respiration in Alocasia macrorrhiza following transfers to high and low light. Oecologia, vol. 86, no. 3, p. 447-453.
SIMS, DA. and PEARCY, RW. 1992. Response of leaf anatomy and photosynthetic capacity in Alocasia macrorhiza (Araceae) to a transfer from low to high light. American Journal of Botany, vol. 79, p. 449-455.

SOUZA, GM., RIBEIRO, RV., SATO, AM. and OLIVEIRA, MS. 2008. Diurnal and seasonal carbon balance of four tropical tree species differing in successional status. Revista Brasileira de Biologia $=$ Braziian Journal of Biology, vol. 68, no. 3B, p. 631-637.

STRAUSS-DEBENEDETTI, S. and BAZZAZ, FA. 1996. Photosynthetic characteristics of tropical trees along successional gradients. In MULKEY, SS., CHAZDON, RL. and SMITH, AP. (Eds.). Tropical Forest Plant Ecophysiology. New York: Chapman and Hall. p. 162-186.

SULTAN, SE. 1992. Phenotypic plasticity and the NeoDarwinian legacy. Evolutional Trends in Plants, vol. 6, no. 2, p. 61-71.

TAIZ, L. and ZEIGER, E. 1998. Plant physiology. Los Angeles: Sinauer Associates Inc. 792 p.

THOMPSON, WA., HUANG, LK. and KRIEDEMANN, PE. 1992. Photosynthetic response to light and nutrients in suntolerant and shade-tolerant rainforest trees. II. Leaf gas exchange and component processes of photosynthesis. Australian Journal of Plant Physiology, vol. 19, no. 1, p. 19-42.

TURNBULL, MH. 1991. The effect of light quantity and quality during development on the photosynthetic characteristics of six Australian rain-forest tree species. Oecologia, vol. 87, no. 1, p. $110-117$.

VALLADARES, F., ALLEN, MT. and PEARCY, RW. 1997. Photosynthetic responses to dynamic light under field conditions in six tropical rainforest shrubs occurring along a light gradient. Oecologia, vol. 111, p. 505-514.

VALLADARES, F., ARANDA, I. and SÁNCHEZ-GÓMEZ, D. 2004. La luz como factor ecológico y evolutivo para las plantas y su interacción con el agua. In VALLADARES, F. (Ed.). Ecología del bosque mediterráneo en un mundo cambiante. Madrid: EGRAF SA. p. 335-369.

VALLADARES, F., WRIGHT, SJ., LASSO, E., KITAJIMA, K. and PEARCY, RW. 2000. Plastic phenotypic response to light of 16 congeneric shrubs from a Panamanian rainforest. Ecology, vol. 81 , no. 7 , p. 1925-1936.

WALTERS, RG. 2005. Towards an understanding of photosynthetic acclimation. Journal of Experimental Botany, vol. 56, no. 411, p. 435-447.

YANO, S. and TERASHIMA, I. 2001. Separate localization of light signal perception for sun and shade type chloroplast and palisade tissue differentiation in Chenopodium album. Plant Cell Physiology, vol. 42, no. 12, p. 1301-1310.

ZHANG, H., SHARIFI, MR. and NOBEL, PS. 1995. Photosynthetic characteristics of sun versus shade plants of Encelia farinosa as affected by photosynthetic photon flux density, intercellular $\mathrm{CO}_{2}$ concentration, leaf water potential, and leaf temperature. Australian Journal of Plant Physiology, vol. 22, p. 833-841. 